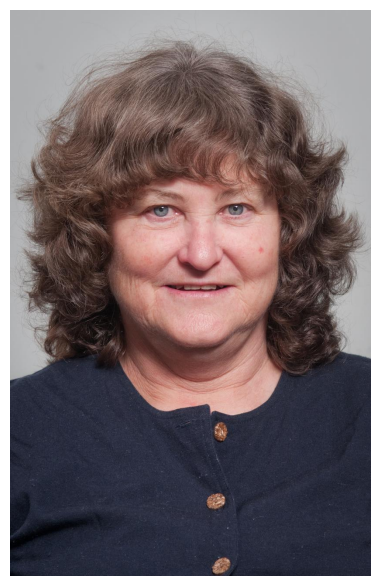

\title{
WOMEN IN SENIOR \\ MANAGEMENT - WHY NOT?
}

\author{
Dr Mervyl McPherson
}

Equal Employment Opportunities Trust

\begin{abstract}
This paper uses data from a recently completed project by the Equal Employment Opportunities Trust on gender parity in senior management positions in the Top 100 companies on the New Zealand Stock Exchange which contributed to the Human Rights Commission's New Zealand Census of Women's Participation 2010. The findings are then compared with Australia, the US, and the UK and discussed in the light of existing research into evidence of the business benefits of more equitable representation, and barriers to women's representation at senior management level. The paper concludes with suggestions for improving gender parity at senior management level.
\end{abstract}

\section{Introduction}

Women make up $46.8 \%$ of the New Zealand labour force (Statistics New Zealand, 2010), but Equal Employment Opportunities (EEO) Trust diversity surveys from 19982007 showed little progress in the proportion of women in the top three tiers of management in mainly EEO Trust member organisations, from $25 \%$ in 1998 to just $30 \%$ a decade later in 2007 . Overseas studies also show slow progress of the proportions of women in senior management (Catalyst, 2010a; Hrdlicka et al, 2010; Gratton et al, 2007a).

The New Zealand Human Rights Commission (HRC) Census of Women's Participation, published biennially since 2004, included information on the proportion of female directors, but not those in senior management. This year the EEO Trust researched women in senior management in the Top 100 companies on the New Zealand Stock Exchange (NZSX).

\section{Method}

The NZSX provided the HRC with a list of the top 200 NZSX-listed companies by market capitalisation, as at May 14, 2010. EEO Trust staff searched websites for information on senior management teams in the top 100 companies, then made contact to clarify, confirm or correct the information.

Senior management was defined as the CEO or managing director, and those managers who report to them. Data was confirmed for $93 \mathrm{CEOs}$, and 88 companies confirmed data for senior management teams reporting to the CEO. Results are presented as percentage of the total 100, with missing data for $7 \%$ of $\mathrm{CEOs}$ and $12 \%$ of senior management teams.

\section{Findings}

Only $4 \%$ of companies were headed by women, and these positions were filled by just two women, with one woman heading three companies. Research and publicly available information suggests that there are no women CEOs among the seven companies for which facts could not be confirmed.

Only $21 \%$ of the 564 filled senior management positions reporting to the CEO were held by women. When the CEO is included, $19 \%$ of senior leadership personnel were women. 
Table 1: Woman in Senior Management NZSX Top100

\begin{tabular}{|lc|}
\hline \multicolumn{1}{|c|}{$\begin{array}{c}\text { Positions held by } \\
\text { women }\end{array}$} \\
\hline CEOs & $4 \%$ \\
\hline $\begin{array}{l}\text { Management positions reporting to } \\
\text { CEO }\end{array}$ & $21 \%$ \\
\hline $\begin{array}{l}\text { Senior leadership team including } \\
\text { CEO }\end{array}$ & $19 \%$ \\
\hline
\end{tabular}

At least $30 \%$ of Top 100 companies had no women in their senior management team. Only one of the 12 companies for which information was unconfirmed appeared to have some women in senior management. Thus it could be that as many as $41 \%$ of the 100 companies had no women senior managers, which would be in line with overseas data: $62 \%$ of Australian companies had no women executive managers (EOWA, 2010:10), and more than $2 / 3$ of top 1500 US companies did not have any women senior executives in 2006 (Dezso \& Ross, 2008:2).
Another $26 \%$ of companies had only one woman in their total senior management team including the CEO, or $29 \%$ for those reporting to CEO.

Women made up less than $20 \%$ of the total senior management team in virtually half of the companies, and in just under half of the teams reporting to the CEO.

Only 1 in 5 companies had $30 \%$ or more women in their senior management team with CEO included, and 1 in 4 had $30 \%$ or more women reporting to the CEO (Table 2).

Table 2: Relative gender parity of NZXS Top 100 companies

\begin{tabular}{|lcc|}
\hline & $\begin{array}{c}\text { Management } \\
\text { including CEO }\end{array}$ & $\begin{array}{c}\text { Team } \\
\text { reporting to } \\
\text { CEO }\end{array}$ \\
\hline $\begin{array}{l}\text { Companies with no women in } \\
\text { senior management }\end{array}$ & $30 \%$ & $30 \%$ \\
\hline $\begin{array}{l}\text { Companies with only one woman } \\
\text { in senior management }\end{array}$ & $26 \%$ & $28 \%$ \\
\hline $\begin{array}{l}\text { Companies with less than 20\% } \\
\text { women in senior management } \\
\text { team }\end{array}$ & $49 \%$ & $45 \%$ \\
\hline $\begin{array}{l}\text { Companies with 30\% or more } \\
\text { women in senior management }\end{array}$ & $20 \%$ & $26 \%$ \\
\hline
\end{tabular}

The most common senior management position held by women was Human Resources Manager or Director (17.4\%), with a total of $20.7 \%$ in the broader HR area including organisational development managers. There was a big gap to the next most common positions for women, Marketing Manager (9.1\%) and Chief Financial Officer (CFO) ( 6.6\%). 
However, the majority $(79.3 \%)$ are doing things other than HR, including legal counsel, corporate services, public affairs, sales, operations, IT and risk management, as shown in Table 3, plus a wide variety of mostly oneoff position titles.

Table 3: Types of positions held by women in senior management

\begin{tabular}{|l|c|}
\hline Position & $\begin{array}{c}\text { Percent } \\
\text { of women in } \\
\text { senior } \\
\text { management }\end{array}$ \\
\hline $\begin{array}{l}\text { HR Manager (also VP, Director) } \\
\text { Organisational Development Manager } \\
\text { Total HR }\end{array}$ & 17.4 \\
& 3.3 \\
\hline Marketing Manager & 20.7 \\
\hline CFO* & 9.1 \\
\hline $\begin{array}{l}\text { Legal Counsel or Head of Legal \& } \\
\text { Regulatory Affairs or Company }\end{array}$ & 6.6 \\
\hline Secretary & 5.8 \\
\hline Corporate Services Manager & \\
\hline Sales Manager & 4.1 \\
\hline Corporate relations/public affairs** & 4.1 \\
\hline General Manager & 3.3 \\
\hline Operations Manager & 3.3 \\
\hline IT Manager & 2.5 \\
\hline Risk/Loss Prevention Manager & 2.5 \\
\hline
\end{tabular}

*CFO includes Group Financial Accountant; Financial controller; Finance Manager as well as CFO.

\section{International comparison}

Table 4: International comparison of women in senior management

\begin{tabular}{|lcccc|} 
& NZ & Australia & US & UK \\
& Top 100 NZSX & ASX 200 & Fortune 500 & FTSE 250 \\
\hline CEO & $4 \%$ & $3 \%$ & $2.6 \%$ & $3.8 \%$ \\
\hline $\begin{array}{l}\text { Senior } \\
\text { managers/executives }\end{array}$ & $21 \%$ & $8 \%$ & $13.5 \%$ & $13.3 \%$ \\
\hline Human Resources & $20.7 \%$ & $37.7 \%$ & - & - \\
\hline
\end{tabular}

There is little difference between countries in the proportion of female CEOs, and New Zealand appears to be doing better than other Western countries for the proportion of women in senior management of the top companies (Table 4), although different ways of defining senior management may affect these comparisons (EOWA, 2010). New Zealand women are less likely to be concentrated in the human resources area, which is not considered a line management position, than in Australia (EOWA, 2009) (Table 4).

\section{Discussion}

Why does it matter?

From an equity or moral perspective, the low proportion of women in the country's top management roles is of concern, but it also matters to business and society. The majority of studies into the relationship between the number of women on boards or at executive level and organisational performance show that higher proportions of senior women are linked to better business outcomes such as return on assets and equity, and suggest that the direction of influence is that more women leads to better outcomes, not vice versa (Catalyst, 2004a \& 2010; McKinsey, 2007; Smith et al, 2006; Desvaux et al, 2008). 
Other studies indicate that diverse perspectives counter dangers of 'group think' and may increase innovation (EEO Trust, 2008a).

Finally, there is the demographic imperative, with women making up nearly half the workforce and dominating amongst university graduates (Ministry of Education, 2009). Organisations and societies need to utilise the full potential of women to maximise the returns of their workforce, and to avoid the costs of women opting out, in terms of loss of investment and skills, plus replacement costs (Kakabadse et al, 2007; Hewlett, 2007).

Why isn't it happening?

Analyses of barriers to women in senior management divide reasons into three interacting categories: individual, organisational and wider social or external factors (Chan, 2010; Strachan et al, 2010).

Figure 1

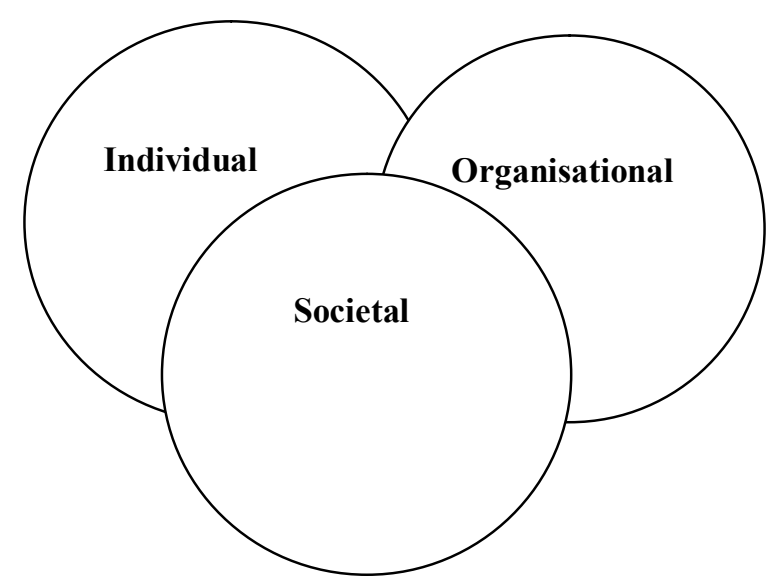

- Individual level

Individual factors related to women being underrepresented in senior management are a tendency to be less proactive than men in seeking out opportunities (Desvaux et al, 2008, Tarr-Whelan, 2009), less adept at negotiating (Babcock \& Laschever, 2003), and less selfpromoting (Kellerman \& Rhode, 2007). Several studies found women are less likely to apply for management positions. For example, a study at Lloyds Bank found that women were more likely than men to exceed performance expectations, but less likely to apply for promotion (Desvaux et al, 2008). "Women think they have to be perfect before they actually apply for jobs. Men with an imperfect record will apply much more readily than women and take the gamble" (Chesterman et al, 2005: 170). Underlying these tendencies may be lack of confidence or self-belief (Tarr-Whelan, 2009; Chesterman et al, 2005).

There are also a number of incorrect assumptions and stereotypes about why women are underrepresented at senior management level, arising from an individual deficit model: they don't want these positions; they have the wrong style of management; they're not qualified or lack the necessary experience; they can't handle these jobs; they can't do these jobs well and be a good mother.

Research addressing these assumptions includes various studies which show that the same proportion of women as men aspire to the top jobs (Catalyst, 2004b; Tarr-Whelan, 2009; Hrdlicka et al, 2010). However, when confronted with the reality of the expectations and demands of the job in terms of hours and priority over home-life, many may choose to 'park' their careers (Watts, 2009; Chesterman et al, 2005; Hewlett, 2007).

While some women may opt out, it is due to a combination of push and pull factors, including inflexible workplaces (Williams et al, 2006) frustrated ambition (Hewlett, 2007), and the dominance of male values in corporate culture (Wirth, 2001), and they are more likely to set up their own business or move to more flexible situations than to stay at home long-term (Eagly \& Carli, 2007; Tarr-Whelan, 2009; Hewlett, 2007; Kakabadse et al, 2004; Catalyst, 2004b; Wirth, 2001)).

Similarly, reviews of research into gender differences in management style conclude there is very little gender difference in style (Eagly \& Carli, 2007). And women today are likely to have more formal qualifications than men, yet even those with MBAs do not progress to the same level as men (Catalyst 2010b; Roth, 2006). 
Women are often perceived to lack the commitment necessary at senior levels, but research suggests this may be due to gender differences in how commitment is demonstrated and measured (Singh \& Vinnicombe, 2000). Others suggest women lack vision and risk-taking attributes necessary for leadership, although these were among the qualities a group of New Zealand women leaders attributed their success to (Pringle et al, 2004), and unchecked and uncalculated risk-taking has been shown to have extremely negative outcomes in recent times.

According to Powell (1990, cited in Vinnicombe \& Bank, 2003), no studies showed women were less suited to managerial positions than men. They may lack the support networks of males, at home and at work, plus do the double shift in the home, but there are no inherent reasons women cannot be effective leaders. If there are any gender specific difficulties they are cultural and structural and can be changed. For example, if women do not reach senior management roles due to the struggle of balancing their roles as worker and mother, (LortieLussier \& Rinfret, 2005; Grummell et al, 2010), this can be attributed to organisational and social deficiencies.

$\bullet$

Organisational level

Looking beyond an individual deficit model to wider structural issues uncovers a number of organisational factors that inhibit female progression. These range from a male dominant corporate culture and informal networks resulting in unconscious bias, stereotyping and preconceptions towards minority status women; through to more overt practices such as lack of developmental opportunities; inflexible workplaces in job design and career paths; and harassment and discrimination.

Women say that the dominance of male values in corporate culture, combined with a belief that women do not make good leaders are the main barriers to their advancement, ahead of conflict with family obligations (Wirth, 2001; European Commission, 2010; Catalyst, 2007). In deciding the criteria of a good leader people look to those already in leadership positions, who are predominantly men, and thus choose masculine traits (Eagli \& Carli, 2007; Kakabadse et al, 2007; Strachan et al, 2010; Catalyst 2010a; Warren, 2009). "Think manager or power, think white male" (Kakabadse et al, 2004:p.97; Catalyst, 2007). Women pay a price for this conflation of masculine traits with leadership traits (Meyerson, 2007; Reciniello, 1999; Gattung, 2010).

One major study concluded that unconscious bias was the number one barrier to women in senior executive and board positions (Piterman, 2010). Men, in particular, are unaware of the unconscious, systemic bias that underlies appointments (Catalyst 2010 \& 2004b; Warren, 2009; Strachan et al, 2009; Eagly \& Carli, 2007; Kellerman \&Rhode, 2007). "Research consistently shows that those in power in organisations tend to recruit in their own image" (Kakabadse et al, 2007:97) and because "women are not like those in power already they are kept out of the inner circles" (Strachan et al, 2010:160). A study of gender discrimination on Wall Street found that workers themselves mentioned "the preference to associate with those of the same gender contributes to systemic inequality" (Roth, 2006). There is also a " 1 or $2=$ diversity' attitude (Bravo, 2007:73), which means women are marginalized, which is itself a barrier to their advancement (Bilimoria et al, 2007).

\section{Figure 2:}

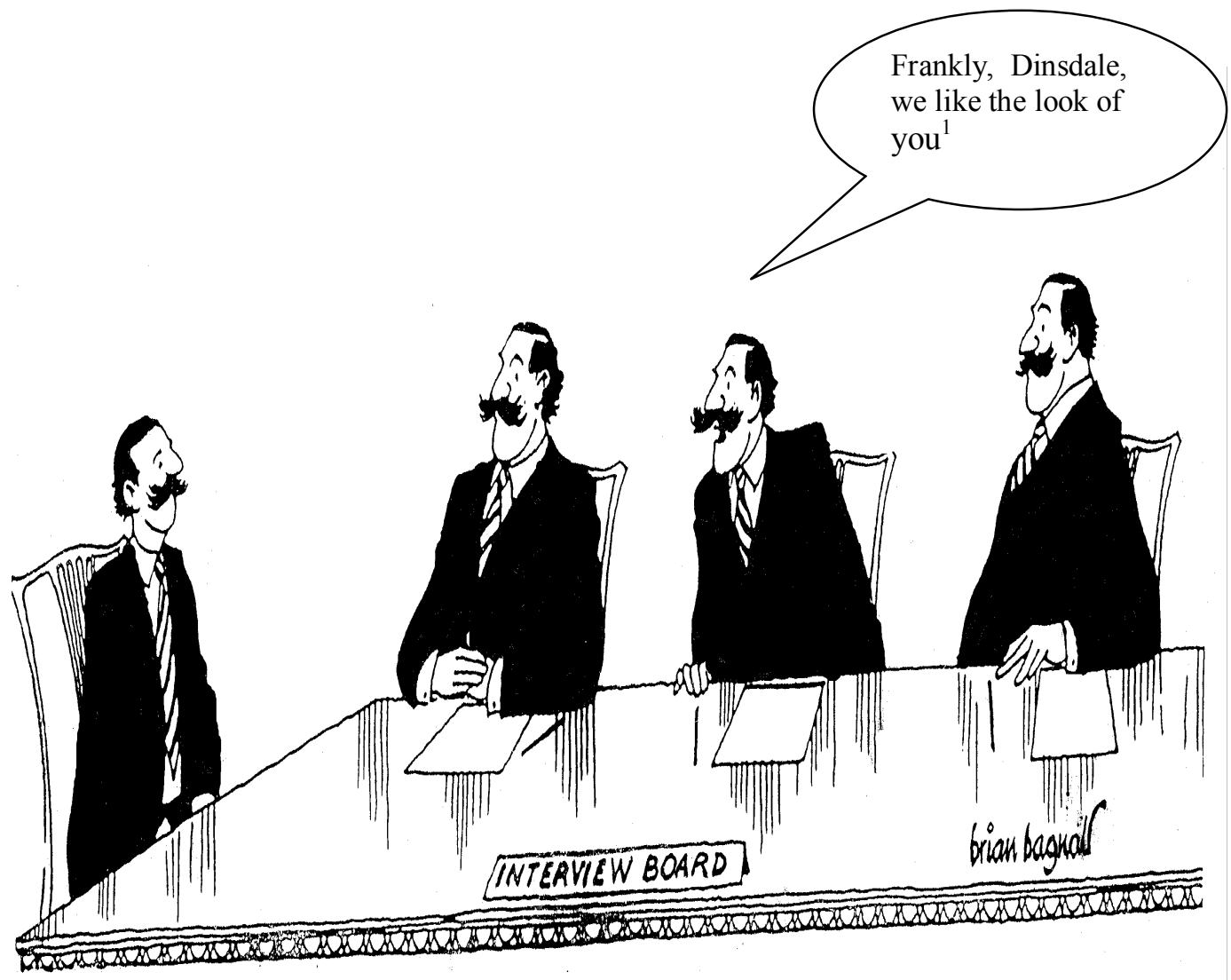


While women attribute their lack of advancement to male stereotyping, preconceptions and exclusion from informal networks, men are more likely to attribute it to women's lack of relevant experience (Kakabadse et al, 2007: 115; Catalyst, 2004b). Studies show that women do not get the same developmental opportunities as men (Chan, 2010; Warren, 2009; Eagly \& Carli, 2007; Roth, 2006). particularly in line management positions such as $\mathrm{CFO}$ and Chief Operating Officer (EOWA, 2009; Eagly \& Carli, 2007). But inflexible male based career paths, including poorly executed talent management systems, may also lead to unintentional gender bias (Warren, 2009). In addition, research shows that mentoring has contributed more to the success of men than women (Lortie-Lussier \& Rinfret, 2005) as women receive a less proactive type of mentoring and from less senior/influential mentors (Ibarra et al, 2010).

The second major barrier for the advancement of women, which is also related to a male dominant culture, is that workplaces and management tracks are based on an obsolete model of a breadwinner male with wife at home (Vinnicombe \& Banks, 2003; Bilimoria et al, 2007). There is an assumption that senior management can only be a full-time undertaking, usually involving very long hours, which conflicts with strong social norms for women to be the primary caregiver (Eagly \& Carli, 2007; Gratton et al, 2007b). Even if domestic work is outsourced, it is women who primarily take responsibility for managing it and stepping in when it fails (Grummell et al, 2009; Rutherford, 2001). Conversely, taking up parttime or flexible work options is seen as indicating less than full commitment to the job (Bilimoria et al, 2007).

Women who do become executives are less likely than male executives to have a spouse at home, and be married with children (Catalyst, 2004b; Grummell et al, 2009; Gratton et al, 2007b).

Finally, sexual harassment and discrimination are still present in many workplaces. Just over half $(53 \%)$ of female senior managers surveyed in an Australian study had experienced gender discrimination such as exclusion, being talked over, and sexual harassment (Rindfleish, 2002). Similarly, $58 \%$ of US employed women say they have been sexually harassed in the workplace and there is evidence in the US of gender discrimination in both pay and promotions (Eagli \& Carli, 2007). In New Zealand, sex and sexual harassment made up $31.5 \%$ of employment related discrimination complaints to the Human Rights Commission in 2009-2010. ${ }^{2}$

\section{- $\quad$ External wider social factors}

Further analysis of barriers to female advancement situates both organisations and individuals in the wider social context in which they operate. This includes the legislative framework and the informal context of social norms in relation to gender equity, as well as the domestic sphere of the family and household.

Despite the Human Rights Act and the Pay Equity Act, Paid Parental Leave and the flexible work amendment to the Employment Relations Act, New Zealand women have still not achieved equity with men in terms of pay and workplace status.

The gender division of labour in the home and lack of gender equity in wider society limit gender equity in the workplace. While $92 \%$ of New Zealand parents believe a father should be as heavily involved in the care of his children as the mother, only $53 \%$ say they actually do share childcare responsibilities (Ministry of Social Development 2006:15), and a majority of New Zealanders still believe women with preschool children should not be in paid work, and those with school age children should work part-time (Gendall, 2003). The need for greater provision of affordable, quality childcare, including out of school care, and the conflict between ideals of motherhood and management also constrain women's participation in paid work (McPherson, 2006; Statistics New Zealand, 2009).

\section{How could gender parity in senior management be improved?}

Efforts focused largely on fixing women and legislating against overt discrimination have only got women so far a new approach needs to address more subtle but entrenched and interacting systemic and societal biases.

\section{- External wider society}

Legislation operates within the context of wider social norms and other constraints, so while providing an essential framework, cannot in itself achieve the change required. While more affordable, quality childcare is needed, research indicates that until men play an equal part in the early lives of their children, the gender division of domestic labour will not change, and hence women will always struggle to achieve equality in the workplace (Department of Labour, 2009). Male only entitlements to paid parental leave have been shown to increase their long-term involvement in childcare (ibid), but are not currently available in New Zealand. In addition, as long as the gender pay gap persists it provides an economic rationale for men continuing to work and women 
compromising their paid work for family needs; a selfperpetuating cycle.

Incentives for men to contribute more at home are needed (Eagli \& Carli, 2007; Wirth, 2001), alongside a reduction in paid working hours, as New Zealand research shows that men's total hours of paid and unpaid work are equal to or greater than women's (Callister, 2005), and Gratton et al (2007b) found that a long working hours culture negatively affected senior men with young children.

Policy changes should be accompanied by greater emphasis on attitudinal change through education on the benefits of gender equity and the reasons it is not being achieved as well as the promotion of role models (European Commission, 2010; Eve-olution, 2005).

The other shift in focus, due to the slow pace of change through other approaches, is to consider targets or quotas. Tarr-Whelan (2009:19) refers to 'the 30\% solution', which is the tipping point at which it is believed women's voices will be heard. It is also the point below which the company culture is unlikely to support women's advancement (European Commission, 2010; Gratton et al, $2007 \mathrm{~b}$ ). While some countries have set mandatory quotas for women on boards (European Commission, 2010), others such as Australia have recently moved to require listed companies to set measurable objectives or targets for the number of women at board and senior executive level - targets must be disclosed to the market and progress reported annually (ASX, 2010).

The Australian Human Rights Commission (2010) is also calling for stronger legislation and enforcement of flexible work as the norm, with protection from discrimination on the grounds of family responsibilities, as happens in the US (Williams et al, 2006). Evidence for the effectiveness of EEO policies and initiatives in relation to gender is mixed (Strachan et al 2010; Konrad, 2007); what is agreed is that effectiveness is constrained by workplace culture, senior management commitment and workloads (EEO Trust, 2008a \& b).

\section{- $\quad$ Organisational level}

"It is extremely challenging to create organisational change... that challenges deeply held beliefs and assumptions that are reinforced by the larger society, but organisations have a role to play. "(Giscombe, 2007).

The numerous areas of organisational practice that can affect women's progress to senior management can be summarised in five broad categories: formal processes; equal opportunities; redesigning career paths and senior roles; workplace culture, diversity implementation, and monitoring; and benchmark targets. All of these have links to the key barrier of male dominant values at senior levels.
Processes: Audit and monitor all processes related to promotion, including mentoring schemes, to ensure they are formalised, transparent and equitable.

EEO: Unless women have the same opportunities as their male peers, including line management roles and assignments, and are being paid the same for the same level of responsibility they will continue to opt out or be excluded from the top level. It will also remain economically rational for women rather than men to compromise their careers for family responsibilities.

Career paths: Recognise the need for different models of career development for men and women with family responsibilities, allowing for time out on non-linear career paths, such as extending the age range for high performance programmes to accommodate parental leave time (Bravo, 2007; Burke, 2007; Vinnicombe \& Banks, 2003). Similarly, challenge automatic resistance to trying a different way of doing things by exploring how senior roles could be effectively restructured (Wisework, 2007). For example, Lee et al (2002) found part-time work was successful for corporate managers with three or more direct reports, despite a belief it could not be done.

Workplace culture: Supportive leaders (Hrdlicka et al; Kellerman \& Rhode, 2007) are essential to achieving a gender-neutral workplace culture Chesterman et al, 2005; Hrdlicka et al, 2010; Eagly \& Carli, 2007) where using flexible work options to balance work and family is not seen as just for women who are not serious about senior management careers (Kellerman \&Rhode (2007). An example of such a culture is Xerox, where "no-one hesitates to reschedule a meeting to take a child to the pediatrician" (Bilimoria et al, 2007:241). To achieve such a culture managers are held accountable for diversity goals, and the result is the CEO and $30 \%$ of managers are women.

Amongst the winners of the EEO Trust Work \& Life Awards 2010 are ANZ New Zealand, Microsoft and Chapman Tripp, all of which have successfully created workplace cultures which normalise flexible working. For example, ANZ New Zealand offers flexible working options to all its employees, regardless of whether they have caring responsibilities. "The bank sees flexibility as a business imperative in an environment where the attraction and retention of key talent is critical and increasing workforce diversity means it is not simply a nice-to-have HR initiative." (EEO Trust, 2010:56).

Evidence of links between organisational practice and women in senior management can be seen at law firm Chapman Tripp. Following the introduction of various measures including flexible working hours (within the constraints of meeting client expectations), holding internal meetings and most client functions in core hours, discouraging long work hours and supporting part-time work, the proportion of promotions that were women increased from $35 \%$ in 2007 to $61 \%$ in 2009 , and the proportion of women promoted from principal to partner increased from 0 to $18 \%{ }^{3}$ 
Some argue that it is time to move the debate away from family issues to the more challenging area of stereotypes, perceptions and prejudices, particularly as many men are not even aware there is a problem let alone what it is (Eve-olution 2005). The solutions include engaging men in gender initiatives (Prime \& Moss-Racusin, 2009; Broderick, 2010), and providing training for senior men so they can better understand how male values and gender stereotyping dominate corporate culture, and thus help men and women work together effectively (Wirth, 2001; Eve-olution, 2005).

Targets: Organisations should also consider setting benchmarks or targets for women in senior management to achieve "critical mass", which is the point at which there is acceptance and appreciation of difference rather than marginalized tokenism and pressure to conform, generally found to be $30 \%$ (Gratton et al, 2007a; TarrWhellan, 2009; Broderick, 2010). For example, Deloittes aimed at $30 \%$, and now $35 \%$ of partners and $30 \%$ of directors are women (Tarr-Whellan, 2009:23). Making it a requirement to have women on selection panels and to put forward women candidates is part of this (Gratton et al, 2007a).

Senior women leaders in a New Zealand study who said they did not experience gender issues were in teams or organisations where the majority of people were women (Pringle et al, 2004:14). Watts (2009:525) noted that when very few women share a situation, the only way they can survive is "by fitting in and colluding with male styles (of management)". Many of these points are exemplified by Teresa Gattung, the first woman to lead a major New Zealand company: "I switched off my 'feminine' side years ago in order to get to the top in a man's world" (Gattung, 2010: p.206). "I was treated like an equal by my male colleagues in the corporate world ... but for me in a way it reinforced my being in 'male' mode". (ibid:211)

\section{- Individual level}

Women need to be more proactive and seek out opportunities - not sit back and wait for them to come to them (Chan, 2010; Tarr-Whelan, 2009; Valeri, 2009). They need to make their intentions known, demonstrate their results and value, and negotiate (Chan, 2010; Eagly \& Carli, 2007; Kellerman \&Rhode, 2007).

Networking (Eagly \& Carli, 2007; Kellerman \& Rhode, 2007; European Commission, 2010), together with finding a good mentor who will be proactive in encouraging women to seek out opportunities, and be influential enough to assist their progress (Ibarra et al, 2010), are necessary to getting those opportunities, but self-belief is also important (Eagly \& Carli, 2007).

Women also need to counteract stereotypes that female qualities are not compatible with effective leadership, or where the same behaviour is treated or labeled differently for men and women, for example, being competent and assertive are seen as positive traits for men and for leaders, but not for women, who are expected to be nurturing, caring and cooperative ( Eagly \& Carli, 2007; Tarr-Whelan, 2009). Gattung (2010:206) missed out on a job because she was considered 'too strong and forthright' for the male chairman to work with comfortably.

On a hopeful note, leadership research supports transformational and collaborative styles, and women manifest these styles more than men by a small amount (Eagly \& Carli, 2007).

\section{Conclusion and recommendations}

There is evidence of benefits to business beyond the moral imperative of having more women at senior management level. The reasons this is not happening are a complex interplay of societal, organisational and individual factors. For individuals to make change they also need changes in workplaces, policy, and within families and wider society. Women need to instigate change, as they have with other gender equity issues, but they need men as allies, particularly those in senior, influential positions in business and government, but also at home.

Further research may look at links between women on boards and women in senior management in New Zealand and, if there are links, the direction of influence. Overseas research suggests that the proportion of women on boards predicts the proportion in senior positions, rather than an increasing proportion in the pipeline coming through the ranks leading to an increase at senior levels (Catalyst, 2010a). Continued monitoring of progress and research on reasons for lack of gender parity in senior management are also needed.

1 Permission to use cartoon by the late Brian Bagnall granted to the author by letter from his widow, Mrs Joanna Bagnall, October 2010. See also Kakabadse et al, 2004:98.

2 Data provided by Human Rights Commission November 2010

${ }^{3}$ EEO Trust Work Life Award Entry 2010.

\section{References}

ASX, (2010): ASX Diversity Guidelines Briefing. http://www.eeotrust.org.nz/content/docs/informati on/Sphinxx $\% 20$ ASX $\% 20$ Gender $\% 20$ Reporting $\% 2$ 0Guidelines.pdf

Australian Human Rights Commission, (2010): 2010 gender equality blueprint. www.humanrights.gov.au

Babcock, L. and Laschever, S., (2003): Women don't ask. Negotiation and the gender divide. Princeton University Press, Princeton and Oxford. 
Bilimoria, D. Godwin, L. and Zelechowski, D., (2007): Influence and inclusion; a framework for researching women's advancement in organizations . In Handbook on women in business and management. Bilimoria \& Piderit (eds), Edward Elgar:232-253.

Bravo, E. (2007): Taking on the big boys or why feminism is good for families, business and the nation. The Feminist Press, City University of New York.

Broderick, E. (2010): Gender equality in the workforce: a feminist approach. Speech,12 August, Australian Human Rights Commission.

Burke, R.J. (2007): Career development of managerial women: attracting and managing talent. In Handbook on women in business and management. Bilimoria \& Piderit (eds), Edward Elgar: 109-131.

Callister, P., (2005): Overworked families? Changes in the paid working hours of families with young children, 1986-2001. Social Policy Journal of New Zealand, 24, 160-184.

Catalyst, (2010a): Targeting inequity: the gender gap in U.S. corporate leadership. www.catalystwomen.org

Catalyst, (2010b): Pipeline's broken promise. www.catalystwomen.org.

Catalyst, (2007): The double-bind dilemma for women in dealership: damned if you do, doomed if you don't. www.catalystwomen.org

Catalyst, (2004a): The bottom line: connecting corporate performance and gender diversity. Catalyst, www.catalystwomen.org.

Catalyst, (2004b): Women and men in U.S. corporate leadership: same workplace, different realities. www.catalystwomen.org

Chan, Elizabeth, (2010): Profile of a successful woman leader, Women and Leadership conference, Australia July 2010.

Chesterman, C., Ross-Smith, A. and Peters, M. (2005): "Not doable jobs!" Exploring senior women's attitudes to academic leadership roles. Womens Studies International Forum, 28:163-180.

Department of Labour, (2009): Men's participation in unpaid care. Wellington.

Desvaux, G., Devillard-Hoellinger, S. and Meaney, M. (2008): A business case for women. The McKinsey Quarterly, September, 2008.
Dezso, C. and Ross, D. (2008): 'Girl power: female participation in top management and firm performance, Working paper No.RHS-06-104, Robert H. Smith School of Business University of Maryland.

Eagly, A.H. and Carli, L.L. (2007): Through the labyrinth. The truth about how women become leaders. Harvard Business School Press, Boston.

EOWA, (2010): EOWA 2010 Australian Census of Women in leadership. Equal Opportunity for Women in the Workplace Agency. www.eowa.govt.au

EOWA, (2009): Pay, power and position. www.eowa.govt.au

Equal Employment Opportunities Trust, 2010: Valuing people, creating value: Bringing work to life 2010. EEO Trust, Auckland

Equal Employment Opportunities Trust, (2008a): Diversity \& Equality - evidence of positive business outcomes and how to achieve them. http://www.eeotrust.org.nz/content/docs/reports/Di versity $\% 20$ and $\% 20$ Equality $\% 20$ Review $\% 20$ \%20June\%202008.doc

Equal Employment Opportunities Trust, (2008b): EEO Trust Work-Life Survey. http://www.eeotrust.org.nz/content/docs/reports/W ork-Life $\% 20$ Survey $\% 202008 . d o c$

European Commission, (2010): More women in senior positions. Key to economic stability and growth. European Union. http://ec.europa.eu/social

Eve-olution Limited, (2005): Women leaders speak out - in search of the "cultured company".

Families Commission, (2008): Give and take. Families experiences and perceptions of flexible work in New Zealand. Wellington.

Families Commission, (2007): It's about time. Towards a parental leave policy that gives New Zealand families real choice. Wellington.

Gattung, T. (2010): Bird on a wire. The inside story from a straight talking CEO. Random House, New Zealand.

Gendall, P. (2003): The roles of men and women in society. International Social Survey Programme, Department of Marketing, Massey University, Palmerston North.

Giscombe, K. (2007): Women in corporate leadership: status and prospects. In Women and leadership. The state of play and strategies for change. Jossey-Bass, San Francisco (383-406). 
Gratton, L, Kelan, E. and Walker, L. (2007a): Inspiring women: corporate best practice in Europe. Lehman Brothers Centre for Women in Business, London Business School.

Gratton, L et al, (2007b): Innovative potential: men and women in teams. Lehman Brothers Centre for Women in Business, London Business School.

Grummell, B., Devine, D. and Lynch, K. (2010): The care-less manager: gender, care and new managerialism in higher education. Gender and Education, 21(2):191-208.

Hewlett, S.A., (2007): Off-ramps and on-ramps. Keeping talented women on the road to success. Harvard Business School Press, Boston.

Hrdlicka, J., Cottrell, D, and Sanders, M. (2010): Level the playing field: a call for action on gender parity in 0Australia. Bain \& Company, www.bain.com

Ibarra, H., Carter, N., and Silva, C. (2010): Why men still get more promotions than women. Harvard Business Review, Sept.80-85.

Kakabadse, A., Bank, J. and Vinnicombe, S. (2004): Working in organisations, $2^{\text {nd }}$ edn, Gower, Burlington.

Kellerman, B. and Rhode, D. (2007): Women and leadership: the state of play. In Women and leadership. The state of play and strategies for change. Kellerman \& Rhode, (eds), Jossey-Bass, San Francisco: 1-64.

Konrad, A. (2007): The effectiveness of human resource management practices for promoting women's careers. . In Handbook on women in business and management. Bilimoria \& Piderit (eds), Edward Elgar:254-276.

Lee, M. et al (2002): Contextual factors in the success of reduced-load work arrangements among managers and professionals. Human Resource Management, 41(2):209-223.

Lortie-Lussier, M. and Rinfret, N. (2005): Determinants of objective and subjective success of men and women. International Review of Administrative Sciences, 71:607-624.

McKinsey and Company, (2007): Women matter. Gender diversity, a corporate performance driver. McKinsey \& Company.

McPherson, M. (2006): New Zealand cultural norms of parenting and childcare and how these relate to labour force participation decisions and requirements. Families Commission, Wellington.
Meyerson, D. Ely, R. and Wernick, L. (2007): Disrupting gender, revising leadership. In Women and leadership. The state of play and strategies for change. Kellerman \& Rhode, (eds), JosseyBass, San Francisco:453-473

Ministry of Education, (2009): Domestic students completing qualifications by age group, gender and qualification level 2001-2008.

http://www.educationcounts.govt.nz/statistics/terti ary_education/retention_and_achievement, COM8

Ministry of Social Development, (2006): Work, family and parenting study. Wellington.

Piterman, H. (2010): Gender potential: a leader's handbook. Major street publishing, Australia.

Prime, J. and Moss-Racusin, C. (2009): Engaging men in gender initiatives. Catalyst.

Reciniello, S. (1999): The emergence of a powerful female workforce as a threat to organizational identity. The American Behavioral Scientist, 43(2):301-323.

Rindfleish, Jennifer, (2002): Senior management women and gender equity: a comparison of public and private sector women in Australia. Equal Opportunities International, 21(7):37-55.

Rutherford, S. (2001): Organizational cultures, women managers and exclusion. Women in Management Review, 16(8):371-382.

Singh, V. and Vinnicombe, S. (2000): Gendered meanings of commitment from high technology engineering managers in the United Kingdom and Sweden, Gender, Work and Organization, 7(1):116.

Smith, N., Smith, V. and Verner, M. (2006): Do women in top management affect firm performance? A panel study of 2,500 Danish firms. International Journal of Productivity and Performance Management, 55(7):569-593.

Strachan, G., French, E. \& Burgess, J. (2010): Managing Diversity in Australia. Theory and Practice. McGraw Hill, New South Wales.

Statistics New Zealand, (2010): Household Labour Force Survey, June 2010 quarter.

Statistics New Zealand, (2009): New Zealand childcare survey 2009.

Tarr-Whelan, Linda, (2009): Women lead the way. Your guide to stepping up to leadership and changing the world. Berrett-Koehler, San Francisco. 
Warren, Anitka K. (2009): Cascading gender biases, compounding effects: an assessment of talent management systems. Catalyst http://www.catalyst.org

Watts, J.H. (2009): Leaders of men: women 'managing' in construction. Work Employment Society, 23:512-530.

Williams, J., Manvell, J. and Bornstein, S. (2006): "Opt out or pushed out?: How the press covers work/family conflict. The untold story of why women leave the workforce. WorkLife Law, Hastings College of the Law, University of California.

Wirth, L. (2001): Breaking through the glass ceiling. Women in management. International Labour Office, Geneva.

Wisework Limited, (2007): Gaining the benefits of parttime working - a toolkit to encourage and support the provision and uptake of good quality part-time work opportunities for senior women. www.wisework.co.uk 